\title{
DISTINCTIONS OF THE CROWDFUNDING MODEL IN AGRICULTURE
}

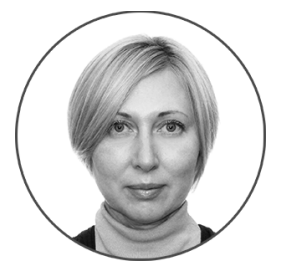

\author{
Natal'ya G. FILIMONOVA \\ Krasnoyarsk State Agrarian University (KrasSAU), Krasnoyarsk, Russian Federation \\ natali_08@mail.ru
}

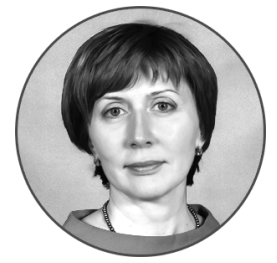

Mariya G. OZEROVA

Krasnoyarsk State Agrarian University (KrasSAU), Krasnoyarsk, Russian Federation ozerova_m71@mail.ru

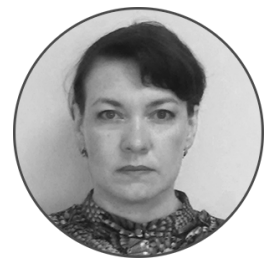

\section{Irina N. ERMAKOVA}

Krasnoyarsk State Agrarian University (KrasSAU), Krasnoyarsk, Russian Federation irena-erm@rambler.ru

\section{Corresponding author}

\section{Article history:}

Received 27 July 2017

Received in revised form

21 September 2017

Accepted 18 October 2017

Translated 8 February 2018

Available online 27 March 2018

JEL classification: 014

Keywords: crowdfunding, crowdinvesting, crowdfunding platform, crowdfunding campaign, farming industry

\begin{abstract}
Importance The article studies organizational and economic aspects of crowdfunding intended to finance agricultural projects. We provide methodological recommendations for designing and implementing the crowdfunding scheme in rural areas.

Objectives We outline methodological recommendations for building a crowdfunding model to finance innovative and investment projects in line with sectoral distinctions of agriculture.

Methods The research is based on general scientific methods of analysis and synthesis, statistical and analytical data on performance results of crowdfunding platforms.

Results We unfold distinctions of the crowdfunding model applied to agricultural projects, and provide our advice on the way agricultural projects should be pitched.

Conclusions and Relevance Being a promising tool to raise the finance of innovative and investment projects in agriculture, crowdfunding has its sectoral distinctions to be considered in order to select a crowdfunding model and arrange project presentation stages. Our recommendations can prove useful for agricultural producers and other entrepreneurs to select an appropriate crowdfunding model of innovative and investment projects in agriculture.
\end{abstract}

(c) Publishing house FINANCE and CREDIT, 2017

The editor-in-charge of this article was Irina M. Vechkanova Authorized translation by Irina M. Vechkanova 
Creating a stimulus for investment is one of the priorities pursued by the economic mechanism of the agricultural sector. The 2013-2020 governmental program for agricultural development and regulation of agricultural markets comprises the interim program, Technical and Technological Retrofitting and Innovative Development, which triggered technological retrofitting of enterprises, increase in variety selection plantings, use of modern holistic technologies of agricultural production, and drew the finance into large investment projects in animal husbandry. However, investment projects have not gained momentum due to insufficient financial aid of the State. According to I. Ushachev, A. Serkov, V. Maslova and V. Chekalin, public investment fell from RUB 9.1 billion (2010) down to RUB 8.7 billion (2015) [1].

Profit and loans still remain the main feed for most agricultural producers in Russia. Fundraising volumes grew by 12.3 percent in comparison with $2010^{1}$. As the State subsidizes interests rates, thus making loans more affordable, the financial position of agricultural enterprises changes. First, it increases the percentage of bank loans in current assets. Second, it reduces a share of equity in assets.

As agricultural enterprises raise more external funds, they figure out that there are not enough credit institutions in the market. Currently, Russian Agricultural Bank and Sberbank serve about 78.5 percent of loans borrowed by agricultural entities.

Alternative finance may well become a good option in this case. Public finance, or crowdfunding, is one of such options.

Researchers of crowdfunding regard it as a type of crowdsourcing, i.e. using general public's resources and information technology to support business, State or society on a voluntary basis. Such views can be found in proceedings by J. Howe, S.R. Sedel'nikov, A.N. Sivaks [2-4].

\footnotetext{
${ }^{\dagger}$ For the source article, please refer to: Филимонова Н.Г., Озерова М.Г., Ермакова И.Н. Особенности применения краудфандинговой модели финансирования в сельском хозяйстве. Финансы и кредит. 2017. Т. 23. № 42. С. 2523-2537.

URL: https://doi.org/10.24891/fc.23.42.2523

${ }^{1}$ Russian State Statistics

Service. URL: http://www.gks.ru/wps/wcm/connect/rosstat_main/rosstat /ru/statistics/publications/catalog/doc_1140096652250 (In Russ.)
}

As J. Howe [2] and N.A. Larionova [5] put it, crowdfunding essentially constitutes project or business finance by persuading many people to make donations generally via the Internet.

A rise of crowdfunding is also mirrored with growing numbers of crowdfunding platforms. According to Massolution's research, in 2010, there were about 200 websites, where business initiatives managed to totally raise USD 854 million. In five years there were 1,250 crowdfunding websites with donations totaling USD 34.4 billion. The crowdfunding industry is forecast to double in its volume, reaching USD 96 billion $^{2}$.

Major crowdfunding websites pertain to the United States of America. Entrepreneurs from any country may pitch or support projects and business interests there as beneficiaries or backers respectively. They can do this on their own or through a representative. For example, Kickstarter unites over 12 million people who successfully support more than 120 thousand creative projects, with the finance approximating USD 3 billion.

Kroogi pioneered the Russian market of crowdfunding platforms in 2007. It was founded by leaders of Planeta.ru and Boomstarter. Modeled like the U.S. platforms, they provide a great deal of methodological guidelines for new users to succeed in crowdfunding endeavors.

Specialized platforms for agricultural ventures have been emerging for recent years. Barnraiser and AgFunder are the leading ones.

There are no special platforms for agricultural businesses in the Russian market yet. However, crowdfunding gains momentum as a source of finance for startups and innovative projects in agriculture. It is enough to look at growing amounts of funds raised on the largest Russian crowdfunding platforms (Boomstarter, Planeta.ru). For instance, in 2014 agricultural projects accounted for two percent of the total amount pledged by backers on the Boomstarter website. In 2015, their share grew up to four percent, with total donations of the platform increasing as well (RUB 53,251,515 up to RUB $91,134,989)^{3}$.

\footnotetext{
${ }^{2}$ Massolution/Crowdsourcing.org 2015CF Real Estate Crowdfunding Industry Report. URL: http://reports.crowdsourcing.org/? route=product/product \& product_id=52
} 
As formulated by V.A.Tegin, B.F. Usmanov, D.Yu. Boldaruk, I.I. Boldaruk, the modern crowdfunding model comprises three fundamental parties, i.e. project initiator suggesting the idea to be financed, certain persons or groups who back the idea, regulatory organization (crowdfunding website) acting as an intermediary $[6,7]$.

K. Wenzlaff, M. Wallhauser, D.E. Guseva and N. Malykhin classify crowdfunding by type of rewards, which are applicable to agricultural projects as well $[8,9]$ :

1) charity. Those who donate are not supposed to receive any reward for their contributions, or token rewards are given (gratitude, special mention in the mass media or on the website). In this case, the crowdfunding website accumulates pledges of backers and transfers them to the project initiator. This type of crowdfunding is intended to support socially important projects, like the construction and repair of social infrastructure facilities in rural areas, assistance to rural community clubs, care facilities, medical ventures, etc.);

2) conventional crowdfunding. It is one of the most popular methods of crowdfunding in all industries, from IT to film production. In exchange for financial aid, agricultural producers usually offer to supply their products positioned as ecologically safe or unique on the preliminary order basis. Beneficiaries may also allow their backers to stay on the farm for several days, participate in crop harvesting, or present them a collection of receipts, etc. As part of this crowdfunding strategy, websites can act as a conduits of rewards. The specifics of such rewards is investigated in proceedings by D.A. Il'enkova, A.Yu. Duk, M.D. Dzhamaldinova [10, 11];

3) crowdinvesting, or equity-based crowdfunding. Backers get a share or an interest in the company's profit. This crowdfunding strategy resembles conventional investment models most of all. It was legally approved and promoted after U.S. President Barack Obama signed the Jumpstart Our Business Startups Act in April 2012, which permitted small investors to put up money in startups and innovative projects in

\footnotetext{
${ }^{3}$ Marishchuk A. Kraudfanding vozrodit sel'skoe khozyaistvo [Crowdfunding will revive agriculture].

URL: https://rb.ru/opinion/crowd-agro/ (In Russ.)
}

the USA [12]. AgFunder (USA) pioneered the crowdinvesting approach in agriculture;

4) debt crowdfunding. Backers are rewarded with interests on their loans. As M.K. Sanin mentions also private interest-free loans, which are primarily granted to socially important projects [13].

Various technologies, products and types of activities facilitate all types of crowdfunding in agriculture. However, sectoral distinctions of agricultural production shall be taken into account in choosing a certain crowdfunding strategy. According to Yu.V. Davydova [14] and B.I. Smagin [15], they influence the performance of agricultural business as a whole.

Fig. 1 depicts factors that determine which crowdfunding strategy should be selected, and what distinctions of agriculture contribute to them.

Social Impact. If the project delivers a socially comprehensible result, that is, products or services the society needs, workplaces in a decaying village and so on, charity and conventional crowdfunding will be the best options notwithstanding some possible yield the project initiators may derive.

Project Scale. Following the underlying crowdfunding principle - many a little makes a mickle, project initiators may well raise quite substantial finance from smaller investors. However, in practice it mainly works for projects in the most popular industries, which are interesting for mass consumption (music, cinema, literature, digital technology). Agriculture follows another path. Production and consumption are more often than not of local nature, being interesting only for those consumers who are geographically close to get a full reward (fresh products) and sense the social effect of the project. Hence the agricultural entrepreneur can hardly ever gather considerable funds to implement large investment projects, counting on conventional crowdfunding only or even debt crowdfunding. In case of large projects, they'd better opt for crowdinvesting and engage professional investors instead of numerous smaller ones.

Profitability of Project and Return on Investment. This is another metric we urge to consider when choosing a crowdfunding strategy in agriculture. If the business is estimated to generate less profit than the average in the industry, the project can hardly lure respectable 
investors, who aspire dividends or interests in profit. In this case, traditional crowdfunding with non-monetary rewards seems to be an appropriate choice. If project profitability is in the mid range (in comparison with competitive types of business), debt crowdfunding will be more reasonable.

Therefore, agricultural entrepreneurs shall thoroughly match the project metrics and economics and key criteria of crowdfunding strategies and advisable scope of the project (Fig. 2).

After the project initiator chooses the most suitable format of fundraising, another issue comes out. They need to decide on what platform the project will be grounded. In this respect, popularity of a crowdfunding website is not the single option to mind, but it is the model of finance that matters.

We enumerate below the main models of fundraising seen in crowdfunding platforms. According to the all-ornothing scenario, the project initiator gets pledged money only if the project reaches the target amount. Otherwise, money is returned to backers. As per the take-it-all scenario, project initiators may take pledges, net of the platform's fees, no matter whether the project gather the declared amount or not. Some platforms combine these models, thus enabling project initiators to choose between two models, while the crowdfunding website adjusts respective fees in line with the extent to which the project attains the financial goal (Table 1).

Resorting to different finance models, crowdfunding business parties evaluate benefits and opt for a certain crowdfunding website.

In the mean time, not every project pitched on websites is necessarily successful. This may be due to the fact that designers rely upon a classical project technology and fail to consider distinctions of the crowdfunding campaign stages. We summarize advice from the leading international and Russian crowdfunding websites and highlight those distinctions.

Setting the Project Goal. The goal should be clear not only for the designer, but also for the public. Goals are often vague and imprecise, i.e. rehabilitation of a farm, recovery of a rural area, development of environmentally friendly production, etc.
The goal shall reflect the reason for fundraising, that is the creation of a new product, the construction of an asset, arrangement for an event, etc. Whereas the target amount proceeds from a crowd, the project initiator should formulate the goal in an original, attractive and flamboyant manner. The goal shall pursue public interests, rather than personal and business ones only. If the project is expensive, it is reasonable to use the deferred goal technique. The project is split into stages, with the goal being set at the initial stage and vital for the project.

Assessment of Financial Needs for Attaining the Goal. The final declared amount usually consists of four components, i.e. the project value, fees of the crowdfunding website and payment systems, costs of rewards to be created and dispatched, taxes.

The project value shall include all costs associated with the idea. However, keeping the budget as low as possible is perceived as the main financial task. In 2016 the average value of an initial agricultural project was RUB 440 thousand on Boomstarter, RUB 309 thousand on Planeta. The record high pledges reached RUB 1 million on Boomstarter (FoxWood project) and RUB 690 thousand on Planeta (LavkaLavka project). As crowdfunding websites advice, ambitious financial goals are justifiable and feasible if the project has at least two qualities below:

- the project conforms to the current trends, resonates with people and has intense information coverage;

- the project author is encouraged by many loyal supporters (investors) who are interested in the project performance;

- repeated project initiated by the author who proved to be competent and trustworthy in the first crowdfunding campaign, demonstrated a reasonable use of raised funds ${ }^{4}$.

If the project succeeds in collecting a sufficient amount of pledges, crowdfunding platforms charge fees on the amount (Table 1). Assessing costs of rewards for investors is the most difficult task at this stage. Project initiators make their own estimates, considering how many rewards are promised and how much they cost. Rewards shall not be a burden for the project since

\footnotetext{
${ }^{4}$ Gorovaya V.V. Prakticheskoe posobie po kraudfandingu [Practical guide on crowdfunding]. Moscow, Planeta.ru Publ., 2016, 125 p.
}

Please cite this article as: Filimonova N.G., Ozerova M.G., Ermakova I.N. Distinctions of the Crowdfunding Model in Agriculture. Digest 
the primary goal is to raise funds. To avoid unexpected expenses, many project initiators set up a limit of rewards, thus making them more valuable. Estimating rewards, project initiators should also include delivery costs into the budget, if rewards are supposed to be delivered.

Resultant pledges remitted to project authors are qualified as income and subject to taxes. An individual, who is a resident of the Russian Federation, shall pay the personal income tax as much as 13 percent, while individuals, who are not residents of the Russian Federation for tax purposes, are charged a 30 percent tax. If the project is pitched by an individual entrepreneur or legal entity, tax payments are assessed in line with the tax treatment applied to them.

The resultant amount comprises all the funds required to perform the project, fees of crowdfunding platforms and payment systems, costs for rewards and tax expenses. The final amount is the financial goal of the project. According to R.A. Dolzhenko, V.V. Ivanov, N.B. Sashenkova, the efficiency of a crowdfunding project can be defined as the ratio of the project target and crowdfunding costs $[16,17]$.

Project Timelines. There are two types of timelines in crowdfunding. The first one is the period planned for the accomplishment of a business idea. As investors need to understand how their pledges are spent, crowdfunding projects are short-term, lasting from six to 12 months. If a big project is concerned, it shall be phased and have a budget. The second term is the period planned for a crowdfunding campaign. As the leading crowdfunding platform recommend, 30-60 days make an optimal time to raise funds ${ }^{5}$. Protracted crowdfunding campaigns (over 50 days) are less successful than shorter ones.

The project promotion begins with pitching the project on the crowdfunding website. The project profile usually features a description and video message.
Addressing the target audience and investors, project initiators form communication tools which are relevant to each particular group. As stated by M.S. Kalinina [18] and S.V. Pozdnyakova [19], such tools vary, ranging from liaison with the mass media, applying to the sectoral leaders for support, mailout, participation in fora, exhibitions and conferences, etc. However, a special focus is put on the project page in social networking media.

Social media are currently regarded as interactive multi-user portals, which not only enable users to communicate, but also unite them according to their interests and needs, thus becoming a pipeline of would-be sponsors. According to E. Mollick, the number of followers the project author has in social networks is not the only thing that matters. The followers should be willing to support the project by reposting its announcement [20]. Table 2 presents key indicators of social activities influencing the outcome of a crowdfunding campaign.

Crowdfunding Campaign Close. Assessing the project at the end of the crowdfunding campaign, project initiators determine the congruence of results with the underlying idea, identify positive and negative aspects and adjust the project, if appropriate. The successful completion of the crowdfunding campaign opens the initial stage of the project performance. At this stage of crowdfunding, project initiators come across another requirement to meet. They have to report on the project completion through their personal accounts in social networks, project website, thus maintaining sponsors' confidence, and securing future projects.

As a conclusion, we shall note that crowdfunding can be an effective tool to implement various projects in rural areas (innovative, environmental, social, etc.). However, like any other method of finance, it has drawbacks and challenging points. Hence it requires thorough planning and elaboration of all its stages.

\footnotetext{
${ }^{5}$ Kraudfanding na baze nefinansovogo voznagrazhdeniya: Kickstarter vs Indiegogo [Crowdfunding based on non-financial rewarding: Kickstarter vs Indiegogo]. URL: http://crowdsourcing.ru/article/kraudfanding_na_baze_nefinansov ogo_voznagrazhdeniya_kickstarter_vs_indiegogo (In Russ.)
} 
Table 1

Characteristic of the most popular foreign and Russian crowdfunding platforms

\begin{tabular}{|c|c|c|c|c|}
\hline $\begin{array}{l}\text { Website and } \\
\text { location }\end{array}$ & $\begin{array}{l}\text { Commence } \\
\text { ment }\end{array}$ & Project Theme & $\begin{array}{l}\text { Finance } \\
\text { Volume }\end{array}$ & Finance Model \\
\hline Kickstarter (USA) & 2009 & $\begin{array}{l}\text { Art, games, journalism, } \\
\text { technology }\end{array}$ & $\begin{array}{l}\text { Over USD } 3 \\
\text { billion }\end{array}$ & $\begin{array}{l}\text { The all-or-nothing scheme of finance. Payments include } \\
\text { the platform charge ( } 5 \text { percent of the project pledges), } \\
\text { payment system's charges. Projects are subject to moderation. } \\
\text { The designer retain the title for the project, with } \\
\text { environmental business ideas and projects being a priority. } \\
\text { Projects for production of genetically modified organisms are } \\
\text { not allowed }\end{array}$ \\
\hline Indiegogo (USA) & 2008 & $\begin{array}{l}\text { Art, games, education, policy, } \\
\text { technology, healthcare, } \\
\text { traveling, fashion, charity }\end{array}$ & $\begin{array}{l}\text { Over USD } 1 \\
\text { billion }\end{array}$ & $\begin{array}{l}\text { The flexible scheme of finance allows to choose } \\
\text { the all-or-nothing or take-it-all scenarios. There are no } \\
\text { geographical restrictions for finance. Payments include a } 5 \\
\text { percent charge for the platform use, } 3 \text { to } 5 \text { percent charge of } \\
\text { Pay Pal, } 25 \text { USD for money transfers outside the USA. Types of } \\
\text { projects are unlimited }\end{array}$ \\
\hline $\begin{array}{l}\text { Crowdfunder } \\
\text { (United Kingdom) }\end{array}$ & 2010 & $\begin{array}{l}\text { Art, sports, education, } \\
\text { technology, business, politics, } \\
\text { charity }\end{array}$ & $\begin{array}{l}\text { Over GBP } 33 \\
\text { million }\end{array}$ & $\begin{array}{l}\text { The all-or-nothing finance. Payments include a } 5 \text { percent } \\
\text { charge, Value Added Tax ( } 20 \text { percent of pledges), charge for } \\
\text { the platform use, charge of Pay Pal ( } 3.4 \text { percent), transfer } \\
\text { charge (GBP 20). Projects are limited. The project initiator } \\
\text { commits themselves to rewarding its financial backers }\end{array}$ \\
\hline Planeta (Russia) & 2012 & $\begin{array}{l}\text { Art, literature, fashion, } \\
\text { journalism, science, society, } \\
\text { social entrepreneurship, } \\
\text { technology, charity }\end{array}$ & $\begin{array}{l}\text { Over RUB } 600 \\
\text { million }\end{array}$ & $\begin{array}{l}\text { The flexible finance scheme allows to choose between all-or- } \\
\text { nothing or take-it-all scenarios. Under the all-or-nothing } \\
\text { scenario, payments include a charge for the platform use as } \\
\text { much as } 10 \text { percent of the project pledges. Under the take-it- } \\
\text { all scenario, the project initiation is to pay a } 15 \text { percent } \\
\text { charge provided the project gathers from } 50 \text { to } 99 \text { percent of } \\
\text { the declared value. Tangible or intangible rewards are } \\
\text { obligatory }\end{array}$ \\
\hline $\begin{array}{l}\text { Boomstarter } \\
\text { (Russia) }\end{array}$ & 2012 & $\begin{array}{l}\text { Art, sports, technology, games, } \\
\text { design, fashion, charity }\end{array}$ & $\begin{array}{l}\text { Over RUB } 300 \\
\text { million }\end{array}$ & $\begin{array}{l}\text { Pledges are collected on the all-or-nothing or up-to-target } \\
\text { basis. Payments include a charge for the platform use as } \\
\text { much as } 5 \text { percent of the project pledges, a } 5 \text { percent charge } \\
\text { of payment systems, personal income tax. The project } \\
\text { designer retains the title. Backers receive rewards }\end{array}$ \\
\hline Agfunder (USA) & 2013 & Agriculture & $\begin{array}{l}\text { Over USD } 34 \\
\text { million }\end{array}$ & $\begin{array}{l}\text { Companies undergo a verification process, with the priority } \\
\text { given to technological projects of high value added. A special } \\
\text { back-up fund is formed for each project (AgFund), with } \\
\text { the minimum investment of USD } 10 \text { thousand }\end{array}$ \\
\hline
\end{tabular}

Note. The amount of finance is specified as of February 1, 2017.

Source:Authoring, based on the overview of crowdfunding platforms

Please cite this article as: Filimonova N.G., Ozerova M.G., Ermakova I.N. Distinctions of the Crowdfunding Model in Agriculture. Digest Finance, 2018, vol. 23, iss. 1, pp. 98-107. 
Table 2

Social activity factors influencing the crowdfunding campaign success

\begin{tabular}{lll}
\hline Indicator & $\begin{array}{l}\text { Average parameters of Top 3 representing agricultural projects on the Russian crowdfunding } \\
\text { platforms in 2016 }\end{array}$ & Boomstarter \\
\cline { 2 - 3 } & Planeta & \\
\hline $\begin{array}{l}\text { The project initiator's number of followers in } \\
\text { social networks: }\end{array}$ & & 425 \\
$\begin{array}{l}\text { Facebook } \\
\text { Vkontakte }\end{array}$ & 1,056 & 272 \\
\hline $\begin{array}{l}\text { Pieces of news and updates in the crowdfunding } \\
\text { campaign account in social networks }\end{array}$ & 633 & 13 \\
\hline The number of comments & 3 & 32 \\
\hline $\begin{array}{l}\text { Shared } \\
\text { in Facebook }\end{array}$ & 12 & 1,427 \\
in Vkontakte & 35 & 318 \\
\hline The number of sponsors/backers & - & 282 \\
\hline Total pledges, thousand RUB & 72 & 1,490 \\
\hline
\end{tabular}

Source: Authoring, based on the overview of crowdfunding platforms

Figure 1

Sectoral distinctions and key criteria for choosing the crowdfunding strategy in agriculture

\begin{tabular}{|c|c|c|}
\hline Sectoral distinctions of agricultural production & $\begin{array}{c}\text { Criteria for choosing a crowdfunding } \\
\text { strategy as part of project } \\
\text { finance in agriculture }\end{array}$ \\
\hline $\begin{array}{c}\text { Local limits of distribution markets } \\
\text { due to perishability of most products }\end{array}$ & Social effect of the project \\
\hline $\begin{array}{c}\text { Production cycle time and long-term payback } \\
\text { period of investment projects }\end{array}$ & $\begin{array}{c}\text { Project scale (financial needs) } \\
\text { Relatively low efficiency } \\
\text { as compared with other sectors }\end{array}$ \\
\hline $\begin{array}{c}\text { Profitability and payback } \\
\text { period the project }\end{array}$
\end{tabular}

Source:Authoring

Please cite this article as: Filimonova N.G., Ozerova M.G., Ermakova I.N. Distinctions of the Crowdfunding Model in Agriculture. Digest 


\section{Figure 2}

The comparative characteristic of crowdfunding types in accordance with key selection criteria

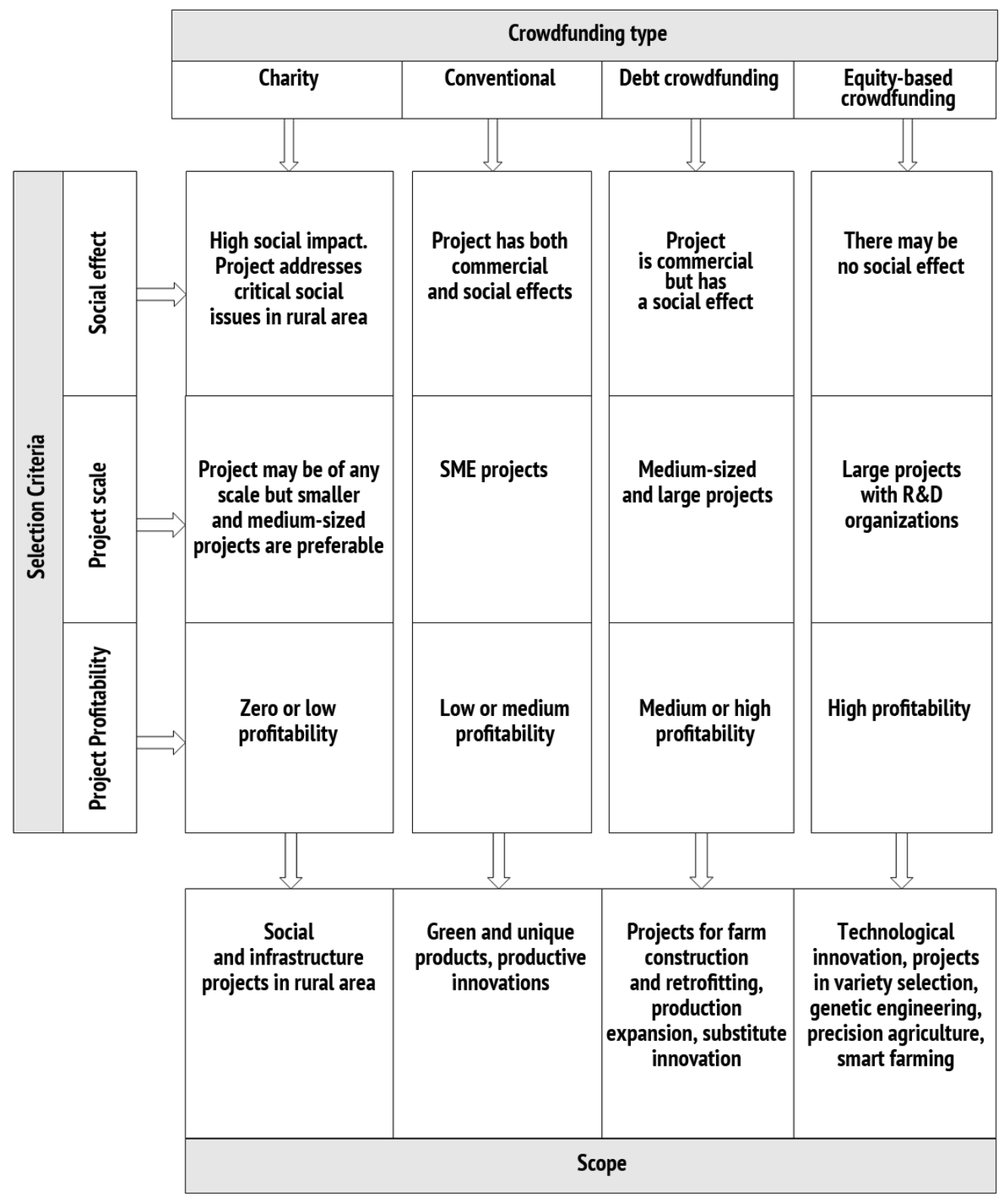

Source:Authoring

Please cite this article as: Filimonova N.G., Ozerova M.G., Ermakova I.N. Distinctions of the Crowdfunding Model in Agriculture. Digest Finance, 2018, vol. 23, iss. 1, pp. 98-107. https://doi.org/10.24891/df.23.1.98 


\section{References}

1. Ushachev I.G., Serkov A.F., Maslova V.V. et al. [Growth and development of agroindustrial ]. APK: Ekonomika, upravlenie $=$ AIC: Economics, Management, 2016, no. 4, pp. 1-15.

URL: http://www.vniiesh.ru/documents/document_20740_Ushachev.pdf (In Russ.)

2. Howe J. Kraudsorsing: Kollektivnyi razum kak instrument razvitiya biznesa [Crowdsourcing: Why the Power of the Crowd Is Driving the Future of Business]. Moscow, Al'pina Pablisher Publ., 2012, 288 p.

3. Sedel'nikov S.R. [Crowdfunding as a new way of financing innovation activity of the startups]. Innovatsionnoe razvitie ekonomiki = Innovative Development of Economy, 2016, no. 1, pp. 82-87.

URL: http://ineconomic.ru/sites/default/files/field_print_version/zhurnal_no_1_31.pdf (In Russ.)

4. Sivaks A.N [Crowdfunding as a special type of crowdsourcing]. Vestnik Samarskogo gosudarstvennogo ekonomicheskogo universiteta = Vestnik of Samara State University of Economics, 2015, no. 11, pp. 30-34. (In Russ.)

5. Larionov N.A. [Financial investor behavior in a crowd-funding model of innovation funding]. Vestnik Saratovskogo gosudarstvennogo sotsial'no-ekonomicheskogo universiteta = Vestnik of Saratov State Socio-Economic University, 2015, no. 2, pp. 77-80. URL: http://www.seun.ru/content/nauka/5/4/doc/2_56_15.pdf (In Russ.)

6. Tegin V.A., Usmanov B.F. [Crowdfunding as a strategy of investment in innovation]. Mir transporta, 2014 , vol. 12, no. 4, pp. 98-106. (In Russ.)

7. Boldaruk D.Yu., Boldaruk I.I. [Crowd-funding as a new source of financing of innovative activity in agriculture]. Russian Journal of Agricultural and Socio-Economic Sciences, 2015, vol. 42, iss. 6, pp. 22-28. URL: https://rjoas.com/issue-2015-06/article_03.pdf (In Russ.)

8. Wenzlaff K., Wallhauser M. [Pooling]. Novoe Sel'skoe Khozyaistvo, 2015, no. 3, pp. 44-47. (In Russ.)

9. Guseva D.E., Malykhin N. [Crowdfunding: Essence, the benefits and risks]. Sovremennaya nauka: Aktual'nye problemy teorii i praktiki. Seriya: Ekonomika i parvo = Modern Science: Actual Problems of Theory and Practice. Series: Economics and Law, 2014, no. 9-10, pp. 30-34.

URL: http://www.nauteh-journal.ru/index.php/ru/---ep14-09/1278-a (In Russ.)

10. Il'enkov D.A. [Crowdfunding: backers' reward models]. Ekonomika i menedzhment innovatsionnykh tekhnologii = Economics and Innovations Management, 2014, no. 11, pp. 58-61. URL: http://ekonomika.snauka.ru/2014/11/6144 (In Russ.)

11. Duk A.Yu., Dzhamaldinova M.D. [Crowdfunding as an investment in innovation process]. Voprosy regional'noi ekonomiki = Problems of Regional Economy, 2016, vol. 26, iss. 1, pp. 27-33. URL: http://unitechmo.ru/upload/files/science/problems-of-regional-economy/file/2016_1.pdf (In Russ.)

12. Kotenko D.A. [Crowdfunding - an innovative investment tool]. Zakon, 2014, no. 5, pp. 140-145. (In Russ.)

13. Sanin M.K. [The history of crowdfunding. The classification of species. Analysis of development prospects and benefits]. Nauchnyi zhurnal NIU ITMO. Seriya: Ekonomika i ekologicheskii menedzhment = Scientific Journal NRU ITMO. Series: Economics and Environmental Management, 2015, no. 4, pp. 57-63. URL: http://economics.ihbt.ifmo.ru/file/article/14199.pdf (In Russ.)

14. Davydova Yu.V. [The features of agriculture influencing efficiency of agricultural production]. Mezhdunarodnyi nauchno-issledovatel'skii zhurnal = International Research Journal, 2016, no. 6-1, pp. 26-28. URL: https://research-journal.org/wp-content/uploads/2011/10/6-1-48.pdf (In Russ.) 
15. Smagin B.I. Ekonomicheskii analiz i statisticheskoe modelirovanie agrarnogo proizvodstva: monografiya [Economic analysis and statistical modeling of agricultural production: a monograph]. Michurinsk, MichSAU Publ., 2007, $153 \mathrm{p}$.

16. Dolzhenko R.A. [Some issues of assessing the effectiveness of crowdfunding in the domestic crowdfunding platform "Planeta"]. Vestnik Omskogo universiteta. Seriya: Ekonomika= Bulletin of Omsk University. Series: Economics, 2016, no. 4, pp. 75-84. (In Russ.)

17. Ivanov V.V., Sashenkova N.B. [Financing introduction of innovative products with crowdfunding technology]. Rossiiskii vneshneekonomicheskii vestnik = Russian Foreign Economic Bulletin, 2015, no. 8, pp. 72-81. URL: http://www.rfej.ru/rvv/id/E002B18F8/\$file/72-81.pdf (In Russ.)

18. Kalinina M.S. [Crowdfunding development as an instrument of social enterprise projects support]. Vestnik Moskovskogo gorodskogo pedagogicheskogo universiteta. Seriya: Ekonomika, 2013, no. 3, pp. 104-110. (In Russ.)

19. Pozdnyakova S.V. [Crowd funding in social business]. Uchenye zapiski Tambovskogo otdeleniya RoSMU, 2015, no. 4, pp. 204-209. (In Russ.)

20. Mollick E. The Dynamics of Crowdfunding: An Exploratory Study. Journal of Business Venturing, 2014, vol. 29, iss. 1, pp. 1-16. URL: https://doi.org/10.1016/j.jbusvent.2013.06.005

\section{Conflict-of-interest notification}

We, the authors of this article, bindingly and explicitly declare of the partial and total lack of actual or potential conflict of interest with any other third party whatsoever, which may arise as a result of the publication of this article. This statement relates to the study, data collection and interpretation, writing and preparation of the article, and the decision to submit the manuscript for publication. 